Since then the district has been traversed by Mr. Gregory, to whose journal as well as to that of Leichhardt your readers are referred. The Peak Downs are now settled, and a considerable population have been digging gold on Theresa Creek and in other places, and mining for copper has made advances to the westward at Mount Drummond.

Some time ago my attention was invited to a statement made by the Gold Commissioner there, to the effect that a "Tertiary River" had been discovered, and I was requested to examine the facts alleged. On breaking up a vast amount of the pebbles and boulders said to have been found in this "Tertiary River," I discovered that there was no clear evidence of anything that could be called Tertiary; but that they were pebbles of probably Quaternary accumulation, consisting of Silurian, Carboniferous, and Secondary rocks with the igneous rocks of the neighbourhood, which latter may be in part of Tertiary age.

In some of the creeks running more to the south-eastward from the Peak Downs, and like Theresa Creek, belonging to the Mackenzie River system (e.g., Crinum Creek), occur bones of Trionyx and Crocodile. A year or two ago I forwarded some of these to my friend Professor Huxley, whose determination I have not yet received.

The naked fact of the discovery of Dinornis in this country is of some value as to Geological inferences.

I may add, in conclusion, that I look forward to further discoveries in the vast accumulations of drift that encumber some of the localities in the neighbourhood of the rivers watering the Leichhardt district, where, among other relics, are those of the Carboniferous formation which now presents only the wreck of a mass of strata that once must have been nearly continuous over an area comprising several degrees of latitude and longitude on one side or other of the Tropic of Capricorn.

ST. Leonard's, New South WaLEs, 19 th May, 1869.

P.S.-I have omitted to mention, that in the collection I exhibited at Paris in 1855, No. 49 consisted of Osseous breccia (Bird bones) from the Coadrigbee Cavern, in New South Wales. So, Dinornis, though new, is not the first of its order.

\title{
THE SO-CALLED HYOID PLATE OF ASTEROLEPIS.
}

Srr,-It may gratify the workers in the Old Red Sandstone to learn that I have solved the puzzle of the so-called Hyoid plate of Asterolepis. It is in reality a Dorsal plate fitting on immediately behind the "Cranial Buckler" in nearly the same position as that occupied by the Dorsal plate of the Coccosteus. I have succeeded in obtaining two fine specimens of the head of the Asterolepis with these plates in their proper positions, from the Great Flag Deposits of Caithness, and I hope to be able to lay them before the Geological Society of London in the course of the next winter. JoHn Mriler.

\section{7, Bloomshury Street, Bedford Sevark,} LoNDoN, 10th July, 1869. 